\title{
RESEARCH
}

\section{Changes in Fungal and Oomycete Community Composition Following Irrigation Reductions Aimed at Increasing Water Use Efficiency in a Containerized Nursery Crop}

\author{
Johanna Del Castillo Múnera, ${ }^{1,+}$ (D) Amisha T. Poret-Peterson, ${ }^{2}$ and Cassandra L. Swett ${ }^{1}$ (D) \\ ${ }^{1}$ Department of Plant Pathology University of California, Davis, CA 95616 \\ ${ }^{2}$ United States Department of Agriculture-Agricultural Research Service Crops Pathology and Genetics Research Unit, Davis, CA 95616 \\ Accepted for publication 15 February 2022.
}

\section{ABSTRACT}

Ornamental production in the United States spans an estimated 267,000 ha and uses approximately $169,000 \mathrm{~m}^{3}$ of water yearly. Ornamental growers, particularly those with air-closed systems, are interested in implementing reduced irrigation technologies such as sensor-controlled irrigation systems to improve water use efficiency in response to water scarcity. To evaluate phytobiome impacts, we utilized an Illumina metabarcoding approach to characterize changes in fungal and oomycete rhizosphere communities of commercially grown poinsettia, complementing previous studies of single-pathogen impacts. Minor reductions (from 54 to $50 \%$ volumetric water content [VWC]) did not have large effects on rhizosphere fungal community structure but shifts in plant health status (symptomatic to asymptomatic) correlated with shifts in fungal diversity and evenness, with an increased abundance of several taxa, including Plectosphaerella cucumerina and Fusarium spp., in symptomatic plants. Further reductions in irrigation $(45,35$, and
$25 \%$ VWC) did not affect overall fungal community composition but the lowest VWC increased the abundance of potential root rot pathogens such as Phoma multirostrata and Plectosphaerella cucumerina. Reduced irrigation volumes decreased oomycete diversity and abundance of several known pathogens in the Phytophthora genus. Addition of a bacterial product (Companion) with putative pathogen-suppressive and drought-tolerance enhancing effects had no influence on fungal community composition or abundance but did increase abundance of some oomycete species at $45 \%$ VWC. This study shows that adoption of reduced irrigation may have greater effects on fungal versus oomycete taxa in the system, with consistent patterns of fungal enhancement, including putative fungal pathogens and beneficial organisms, and oomycete suppression.

Keywords: amplicon sequence variants, ASVs, fungal diversity, ornamental crops, sensor-controlled irrigation
Ornamental production in the United States, including nursery, greenhouse, and propagation facilities, is a significant contributor to agriculture, with a national average of 267,000 ha (USDA-NASS 2019), generating $\$ 13.3$ billion in annual revenues (White et al. 2019). In order to meet market demands for quality, ornamental growers rely on frequent irrigation, which is usually dependent on high-quality ground or municipal water (Fulcher et al. 2016; Lamm et al. 2017; Warner et al. 2018). On average, greenhouse

†Corresponding author: J. Del Castillo Múnera; jdelcastillo@ucdavis.edu

Funding: This research is based upon work that is supported by the U.S. Department of Agriculture-National Institute of Food and Agriculture under award number 2014-51181-22372.

$\boldsymbol{e}$-Xtra: Supplementary materials are available online.

The author(s) declare no conflict of interest. and nursery facilities use $169,000 \mathrm{~m}^{3}$ of water yearly (Ristvey et al. 2019). Climate change and water overuse have driven a reduction in water availability and quality (Connor 2015; Elliott et al. 2014; Falkenmark 2013), and water security is a major challenge in ornamental production (Lamm et al. 2017; Ristvey et al. 2019; White et al. 2019). In order to reduce water inputs, growers have shown an interest in implementing water conservation technologies such as sensor-controlled irrigation (SCI) systems.

As a standard practice, ornamental crops are typically grown under high volumetric water content (VWC) with frequent irrigation. Reduced irrigation systems such as SCI offer the opportunity to more precisely apply irrigation water and substantially decrease water inputs without affecting yield (Costa et al. 2007; dos Santos et al. 2003). However, according to a national survey of commercial producers (White et al. 2019), growers expressed uncertainty in regards to limiting the effects of reduced water inputs on plant pathogens (Lamm et al. 2019); particularly root-infecting pathogens, which tend to be facilitated by water stress (Swett 2020). Root rot diseases caused by oomycetes in the genus Phytophthora 
and Pythium, as well as diverse fungal pathogens, including species of Fusarium, Botrytis, and Rhizoctonia, are recurrent challenges for producers (Del Castillo Múnera and Hausbeck 2016; Erwin and Ribeiro 1996; Parke et al. 2014; Weiland 2011). Water availability plays a key role in pathogen dispersion and differentiation (Granke et al. 2009; Hausbeck and Lamour 2004; Parke et al. 2014; Swett 2020); and water stress can enhance crop susceptibility to pathogen infection (Bostock et al. 2014; Del Castillo Múnera et al. 2019a; MacDonald 1982; Swett 2020).

To understand whether sensor-based irrigation systems influence root and crown rot development, we previously evaluated effects of SCI on tomato-Phytophthora capsici interactions. Although pathogen colonization and disease incidence was enhanced under reduced substrate moisture, moderate water reductions had minor or no negative effects on plant health, indicating the potential to reduce water input without generating an increase in losses due to disease (Del Castillo Múnera et al. 2019a). Similarly, studies of the effect of reduced irrigation on Pythium root rot (Pythium aphanidermatum) in commercial poinsettia production indicated that it was possible to reduce irrigation inputs down to $35 \%$ VWC from the grower standard of 54\% VWC, achieving water reductions of $13.8 \%$, without influencing Pythium root rot, although severe reductions in substrate moisture (25\% VWC) increased Pythium root rot severity (Del Castillo Múnera et al. 2019b).

Although these single-pathogen studies are illuminating, they offer a limited lens in which to capture effects of irrigation practices on endophytic and soilborne organisms at the community level. It is plausible that there are many additional facultative pathogens that are facilitated by reduced irrigation practices, beyond those selected for study, which may compromise plant health and marketability. There may also be unforeseen impact on beneficial microbes that help suppress pathogens, both those present in situ and those added for disease management. With advances in cultureindependent tools, it is possible to evaluate the effects of reduced irrigation practices on whole fungal and oomycete communities associated with plant hosts. Such studies can lend important specific information on pathogen risks in specific production systems, as well as more general insights into pathogenic taxa which have a stronger response to reduced irrigation-information which may be applicable to a broad range of production systems.

The effects of different irrigation regimes on microbial communities have predominately focused on bacteria (Felsmann et al. 2015; Fierer et al. 2003; Starke et al. 2017) and there are, to our knowledge, no studies of microbial community changes under reduced irrigation in any containerized greenhouse crop. One study on fungal communities in California Mediterranean annual grasslands indicated that the dominant soil fungal communities remained unaffected by dry-down or wet-up periods in soils (Barnard et al. 2013). Similarly, a study of the effect of furrow-irrigated, surface-drip, and micro-sprinkler irrigation of a peach orchard showed that total soil microbial community biomass and composition were not affected by deficit irrigation but were altered in response to different irrigation methods (Dangi et al. 2016).

To investigate the community-scale effects of reduced irrigation, we utilized a metabarcoding approach to assess changes in rhizosphere fungal and oomycete communities in commercial, containerized poinsettia (Euphorbia pulcherrima). We aimed to assess shifts in fungal and oomycete communities (i) under minor versus severe irrigation reductions and, within this, (ii) in the presence of the pathogen P. aphanidermatum; and (iii) in the presence of Bacillus subtilis GB03 (Companion), a putative biological control effective against a range of root pathogens. The latter two treatments were included to complement the study by Del Castillo Múnera et al. (2019b) on the effect of reduced irrigation on individual pathogen dynamics and place this work in the context of whole microbial community changes.

\section{MATERIALS AND METHODS}

Commercial greenhouse study: Implementing a set-point based SCI. Irrigation treatments. We collaborated with a commercial greenhouse in Carroll County, Maryland to evaluate effects of minor irrigation reductions in potted poinsettia on rhizosphere fungal and oomycete community composition, as well as on overall plant health. A set-point-based SCI system was set to irrigate 11-week-old poinsettia 'Viking red,' produced as described by Del Castillo Múnera et al. (2019b).

The experiment was conducted over a 10-week period (August to November 2016) with four independently controlled irrigation plots, each containing approximately 600 plants. Two plots were designated to each of the two irrigation treatments: (i) grower standard irrigation practice (GI; averaging $54.2 \%$ VWC) and (ii) setpoint SCI (target of $45 \%$ VWC, actual average 50\% VWC). Substrate VWC was monitored with two EM50R data loggers (Meter Group, Inc., Pullman, WA) on a 5-min basis during the duration of the study. In the SCI irrigation treatment, VWC measurements were transmitted to the Sensorweb software (Mayim LLC, Pittsburgh, PA) and irrigation was activated whenever the averaged VWC was below $45 \%$ VWC. During the study, the VWC for the SCI treatment was $50.3 \%$, generating $8.5 \%$ in water savings compared with the GI treatment.

Plant health monitoring and root collection for downstream community analyses. Aboveground plant health was evaluated four times, at 2-week intervals, starting from initiation of the irrigation treatment. We monitored for stunting, chlorosis, wilting, and defoliation, and symptomatic plants were flagged. After the 8-week monitoring period, we evaluated flagged plants for root rot.

For fungal and oomycete community analyses, root samples were collected from 10 plants which sustained rot in $10 \%$ or more of the root ball (symptomatic plants) (Del Castillo Múnera et al. 2019b) and 10 plants with no aboveground symptoms and no initially apparent root rot (asymptomatic plants). Five randomly selected lateral roots (approximately 10 to $50 \mathrm{~mm}$ in length) were removed from each plant and washed with tap water, weighed, and visually assessed for the presence of root discoloration. Because roots were selected randomly, for most symptomatic plants, this included a mix of roots with and without apparent necrosis. For asymptomatic plants, although initial assessments at the time of plant collection did not detect root rot, in some rare instances downstream root ball processing resulted in detection of minor root discoloration. In the rare occurrence that a discolored root was randomly selected, it was included in the study to preserve the integrity of the random sampling strategy. Roots were surface disinfested two times in $0.1 \%$ solution of Tween 20 for $30 \mathrm{~s}$ and $70 \%$ ethanol for $15 \mathrm{~s}$, then washed with sterile distilled water. Approximately $3 \mathrm{~g}$ of root tissue was stored in glass vials at $-20^{\circ} \mathrm{C}$ until DNA extraction (described below).

Controlled greenhouse study: Evaluating the effect of further reduction in irrigation volume. Experimental design and treatments. The purpose of the study was to explore effects of further reductions in irrigation inputs which were not feasible to apply in the commercial greenhouse, due to producer concerns about impacts on crop marketability. Within each irrigation treatment, we artificially inoculated the oomycete pathogen $P$. aphanidermatum in order to assess overall community changes of reduced irrigation in the presence of a known root rot pathogen. Addition of B. subtilis GB03 (Companion) (Growth Products, Ltd.) allowed us to assess 
community changes under reduced irrigation in the presence of a putative biological control and plant-growth-promoting organism.

Potted poinsettia plants ('Christmas eve red') were initially grown at the commercial facility in $15-\mathrm{cm}$ pots containing potting medium (60\% peat and $40 \%$ perlite), under conditions described by Del Castillo Múnera et al. (2019b). At 9 weeks old, plants were brought to the University of Maryland Plant Science greenhouses (College Park, MD), and experiments one and two were initiated when plants were 10 and 11 weeks old, respectively. The experiment was arranged in a randomized complete block split plot design with two blocks (Fig. 1). Irrigation treatment was the main plot; each irrigation treatment contained eight randomly distributed noninoc-

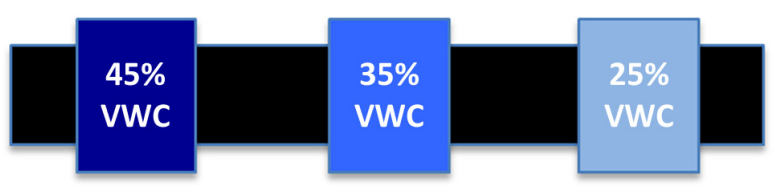

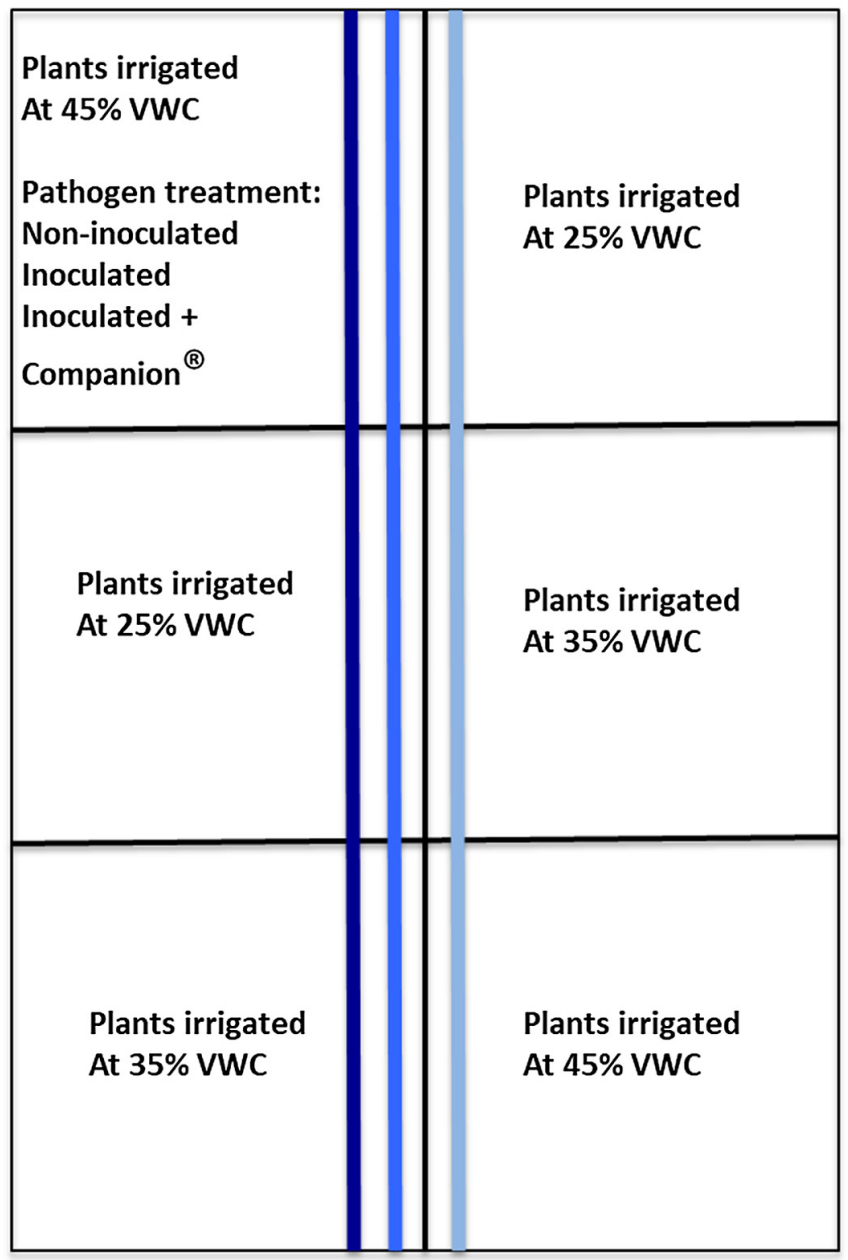

Fig. 1. Controlled greenhouse study experimental design. Scheme of one bench implemented in the experimental setting. The experiment was arranged in a randomized complete block split-plot design with two blocks. Irrigation treatment was the main plot; each irrigation treatment contained eight randomly distributed noninoculated, Pythium aphanidermatum-inoculated, and P. aphanidermatuminoculated + Companion-treated plants (subplots). Corresponding irrigation laterals on each bench were controlled by individual $\mathrm{nR} 5-\mathrm{DC}$ nodes (Meter-Group, Inc.) that were attached to DC latching solenoids on an irrigation manifold connected to a pressure controlled main water line. $\mathrm{VWC}=$ volumetric water content. ulated, $P$. aphanidermatum-inoculated, and P. aphanidermatuminoculated + Companion-treated plants (subplots). This experiment was conducted twice; experiment 1 started in October 2016 and experiment 2 in November 2016.

The irrigation treatments were applied with the set-point-based SCI and consisted of (i) well-watered, using the same VWC applied in the commercial greenhouse (45\% VWC); (ii) mid-range substrate moisture (35\% VWC); and (iii) low-range substrate moisture $(25 \%$ VWC). Within each irrigation treatment, we evaluated three pathogen treatments: noninoculated, inoculated, and inoculated and treated with Companion. Plants were inoculated with $P$. aphanidermatum by adding $3 \mathrm{~g}$ of colonized millet into $3-\mathrm{cm}-$ deep wells positioned at $0.5 \mathrm{~cm}$ from the crowns, as described by Del Castillo Múnera et al. (2019b). Companion was applied as a drench at a rate of $2.5 \mathrm{ml} /$ liter 1 week before inoculating the plants with $P$. aphanidermatum.

Disease monitoring. Aboveground plant health was visually assessed at 7-day intervals from 7 to 49 and 56 days postinoculation for experiments 1 and 2, respectively, using a 1-to-5 scale (Del Castillo Múnera et al. 2019b; Lookabaugh et al. 2018). Briefly, $1=$ no symptoms; 2 = cupping of lower leaves and slight stunting; 3 = moderate stunting, wilting, and chlorosis; $4=$ severe wilting and or stunting; and $5=$ plant death. Upon experiment completion, shoots of each plant were cut from the base of the crown, oven dried at $55^{\circ} \mathrm{C}$ for 5 days, and weighed. Roots were removed from the pots, washed under running tap water, and weighed. Roots were processed as described above for the commercial greenhouse study for community analyses.

DNA extraction, PCR, and sequencing. Approximately $3 \mathrm{~g}$ of surface-sterilized root tissue was placed in 8-ml glass vials, stored at $-20^{\circ} \mathrm{C}$, and lyophilized. Lyophilized tissue was macerated and $0.5 \mathrm{~g}$ was placed in 96-deep well plates. DNA extractions were performed in the Center for Genome Research and Biocomputing (CGRB) at Oregon State University (OSU), Corvallis, OR, using a Tissue Lyser II with the Omega Biotek kit (Norcross, GA) for standard plant extractions.

The fungal and oomycete internal transcribed spacer unit 1 (ITS1) was PCR amplified following the protocol of Redekar et al. (2019). We used the primer pair ITS1F (Gardes and Bruns 1993) and ITS2 (White et al. 1990) for fungal PCR assays and MiSeq ITS6 and MiSeqITS7 (Redekar et al. 2019) for oomycete amplifications. Dual-indexed libraries were prepared via two-step PCR using the Nextera DNA Library preparation Kit and Nextera Index Kit (Illumina, San Diego, CA). The same barcodes were used for amplification of fungal and oomycete ITS regions from the same sample. Reactions consisted of $3.5 \mathrm{mM} \mathrm{MgCl} 2,1 \times$ buffer, $800 \mu \mathrm{M}$ dNTPs, $0.4 \mu \mathrm{M}$ each set of primers, $1 \mathrm{U}$ of Platinum Taq polymerase, and $1 \mu \mathrm{l}(50 \mathrm{ng})$ of DNA in a $25-\mu 1$ reaction volume. Amplifications were performed on a Bio-Rad DNA Engine Peltier Thermal Cycler PTC-200 or Applied Biosystems Veriti Thermal cycler (Foster City, $\mathrm{CA}$ ) with initial denaturation at $94^{\circ} \mathrm{C}$ for $2 \mathrm{~min}$; followed by $35 \mathrm{cy}-$ cles of $94^{\circ} \mathrm{C}$ for $45 \mathrm{~s}, 60^{\circ} \mathrm{C}$ for $30 \mathrm{~s}$, and $72^{\circ} \mathrm{C}$ for $1 \mathrm{~min}$; and a final extension at $72^{\circ} \mathrm{C}$ for $10 \mathrm{~min}$. Amplicons were visualized on $2.5 \%$ agarose gel. PCR products from fungal and oomycete amplifications were pooled together and submitted to the CGRB at OSU for sequencing on an Illumina MiSeq v3 via 250-bp paired-end runs.

Sequencing processing and statistical analyses. Sequence preprocessing. The demultiplexed sequences (read 1 and 2 ) were initially quality checked using FastQC (version 0.11.5) (Andrews 2010); then, the primers were removed from the fungal and oomycete amplicons using cutadapt (version 1.10) (Martin 2011). The sequences were further trimmed to remove 30 bases from each end representing the small subunit and 5.8S ribosomal genes 
from the reads and to extract only the ITS1 region. Sequences are available at NCBI, BioProject PRJNA804966.

Amplicon sequence variant inference and taxonomic classification. We used dada2 (version 1.4.0) to generate amplicon sequence variants (ASVs) from the preprocessed fungal and oomycete ITS reads (Callahan et al. 2016). Prior to ASV inference, the reads were filtered, trimmed (minimum length $100 \mathrm{bp}$ and maxEE $=2$ ), and merged, using a BAND_SIZE of 32. The merged sequences were then checked for chimera and taxonomically classified. Taxonomy was assigned to the ASVs using the UNITE database (Abarenkov et al. 2010) for fungal ITS sequences, and the oomycete database from Redekar et al. (2019). ASVs were also searched against NCBI nucleotide collection (nr/nt) using BLAST (Altschul et al. 1990) to remove plant, nonfungal, and nonoomycete sequences. Following processing, libraries from samples with $<100$ sequences were removed. Across both the commercial and controlled greenhouse studies, 7,935,004 and 495,185 sequences were obtained for the fungal and oomycete communities, respectively.

Statistical analyses. For each library (fungal and oomycete), samples from the commercial greenhouse study and controlled greenhouse experiments were analyzed separately. For the controlled greenhouse study, there were no differences between the experiment replicates; therefore, data were analyzed together. The relative ASV abundance was estimated by dividing the absolute ASV abundance by the total number of sequences per sample. $\alpha$-Diversity of the communities, defined by irrigation, pathogen, and biocontrol treatments, was estimated by ASV richness and the Shannon and Simpson indices, using the R package phyloseq 1.16.2 (McMurdie and Holmes 2013). Statistical analyses of $\alpha$ diversity were performed on SAS, using a proc mixed procedure, where irrigation treatment and plant health status were fixed variables.

$\beta$-Diversity was estimated by calculation of Bray-Curtis distances using the $\mathrm{R}$ package vegan (Oksanen et al. 2019). To determine whether reduced irrigation systems or pathogen treatment significantly altered the community composition, we performed twofactor permutational multivariate analysis of variance using the adonis function of the R package vegan (Oksanen et al. 2019). Plots of taxonomic abundances, principal coordinate analysis (PCoA), and heat maps were generated using the $\mathrm{R}$ packages phyloseq and ggplot2 (Fiske and Chandler 2011).

Differential abundance of ASVs among irrigation systems for commercial and controlled greenhouse studies was estimated with DESeq2 for fungal and oomycete libraries. Data were initially filtered to retain ASVs present in five samples at a total abundance of 50. For comparisons, the highest irrigation treatment for each study (GI for commercial and 45\% VWC for the controlled greenhouse study) were set as controls, and compared against the SCI for the commercial study and 35 and $25 \%$ VWC for the controlled greenhouse study, respectively.

To infer the ecological guild of fungal taxa, ASVs collapsed into species designations were analyzed using FUNGuild (Nguyen et al. 2016). We present results for ASVs that had taxonomic assignments in the UNITE database and were considered "probable" or "highly probable" by FUNGuild. The FUNGuild trophic mode and guild assignments are displayed on relative abundance heat maps constructed using the ComplexHeatmap package in $\mathrm{R}(\mathrm{Gu}$ et al. 2016). Heat maps for "possible" assignments are available in the Supplementary Material. A literature review was used to provide additional trophic information on common fungi (a list of citation used in this section is as Supplementary Table S1) and oomycete species detected in this study.

To determine whether there was an association between fungal community composition and variables that reflect disease symptoms, multivariate distance matrix regression (MDMR) analyses were performed for each study. Disease symptoms were fresh root weight and root rot percentages for the commercial study, and shoot growth, fresh root weight, and disease severity for the controlled greenhouse experiment. In both cases, disease symptom predictors were z-scored and a Bray-Curtis distance matrix used in MDMR analyses implemented in the "MDMR" R package (McArtor et al. 2017). We also conducted post hoc analyses to determine which ASVs contributed the most to a significant association between fungal community composition and disease symptoms. ASVs found to have the largest effect sizes were graphed as a $\mathrm{z}$-scored relative abundance heat map using gplots (Warnes et al. 2020).

\section{RESULTS}

Commercial greenhouse. Fungal community composition. After preprocessing and filtering, we obtained, in total, 1,040,533 fungal sequences that were present in the 40 root samples processed. The sequences were resolved into 269 ASVs. The ASVs belonged to 15 classes, with the Sordariomycetes (36\%) as the most abundant group among both irrigation treatments and plant symptom status. Species of class Agaricomycetes were more abundant in roots of asymptomatic plants $(38 \%)$ and less abundant $(10 \%)$ in roots of symptomatic ones at both irrigation treatments. Similarly, species of Saccharomycetes were more abundant in roots of asymptomatic (5\%) than symptomatic (1\%) plants at both irrigation treatments; an additional 10 classes each had an abundance of $<1 \%$ (Fig. 2). ASVs that were classifiable only as fungi were $31 \%$ of the libraries.

Based on $\alpha$-diversity analyses, plant health had a significant effect on the number of ASVs $(P=0.0001)$. Symptomatic plants from both irrigation treatments (GI and SCI) had seven ASVs more than the asymptomatic plants. Irrigation treatment did not have a significant effect $(P=0.224)$ on the number of ASVs observed (Table 1). Irrigation and plant health status did not have a significant effect on Shannon or Simpson indices $(P>0.05)$ (Table 1). The Shannon index varied from 1.52 to 1.91 and the Simpson index from 0.62 to 0.74 (Table 1 ).

Community structure. Plant health status (symptomatic versus asymptomatic) had a significant effect (adonis $P=0.01$ ) on the fungal community structure, but not irrigation treatment (adonis $P=0.139$ ) (Fig. 3). Further exploration of the among-group diversity between plant health status and irrigation treatment was examined using PCoA (Fig. 3). The first principal coordinate axis captured $31.5 \%$ of the variability but the samples did not clearly group by irrigation treatment or plant health along this axis. Asymptomatic plants (low percent root rot) separated from symptomatic plants (high percent root rot) along the second principal coordinate axis, which captured $18.2 \%$ of the variability in the fungal communities.

Based on differential abundance of sequence variants analyses, the abundance of one ASV corresponding to one unidentified Fusarium sp. significantly increased by a 3.8 to $7.01 \log _{2}$ fold-change in symptomatic plants $(P=0.02)$ compared with asymptomatic plants for both irrigation treatments. Although differences were not significant, there was a trend in which other ASVs, including Phoma multirostrata and Plectosphaerella sp., exhibited a twofold or greater change in abundance in roots of symptomatic plants than asymptomatic ( $P=0.568,0.841$, and 0.765 , respectively).

MDMR analyses showed that there was a significant association between fungal community structure and fresh root weight $(P=0.024)$ and root discoloration percentage $(P=0.002)$. Post hoc analyses identified 16 ASVs with large effect sizes, indicating that they contribute the most to the finding of a significant association between disease symptoms and fungal community 
structure (Supplementary Fig. S1). In particular, ASVs classified as Agaricomycetes, Blastobotrys, Sebacinales, and fungi had lower abundances in symptomatic plants regardless of irrigation treatment.

Fungal ecological guild diversity. The trophic mode and guild of fungal ASVs collapsed into species designations were analyzed in FUNGuild, which assigned "highly probable" or "probable" functional roles for 21 species; these species represented between 16.9 and $49.5 \%$ of the fungal communities. Most of the assigned species (57\%, or 12 of 21 ) were classified as saprobes, with $58 \%$ of them, including taxa such as Plebia sp., Ascocoryne sp., and Hyaloscypha sp. (all apothecia-producing fungi), were only present in the plants under the higher irrigation treatment (GI), with higher abundances in the roots of symptomatic plants (Fig. 4). The beneficial
Talaromyces sp. (Halo et al. 2019) was present with higher abundance in the asymptomatic plants $(0.06 \%)$ under the GI treatment and in similar abundance $(0.01 \%)$ in plants from all of the irrigation treatments. Approximately $23 \%$ ( 5 of 21 ) of the species were classified as pathotrophs, with taxa such as Plectosphaerella sp. (previously described as a root rot pathogen of ornamentals) (Elmer et al. 2020) present in all of the treatments, but with higher abundance in the roots of symptomatic plants under the GI than all of the other irrigation treatments. The plant pathogen taxa Sclerotinacea (predominately crown and stem rot pathogens) was present with lower abundance in plant roots irrigated under the GI treatment. A lower number of species ( 2 of 21 ) were classified as symbiotrophs and were only present in roots of symptomatic plants under both irrigation treatments (Fig. 4). We also examined the FUNGuild

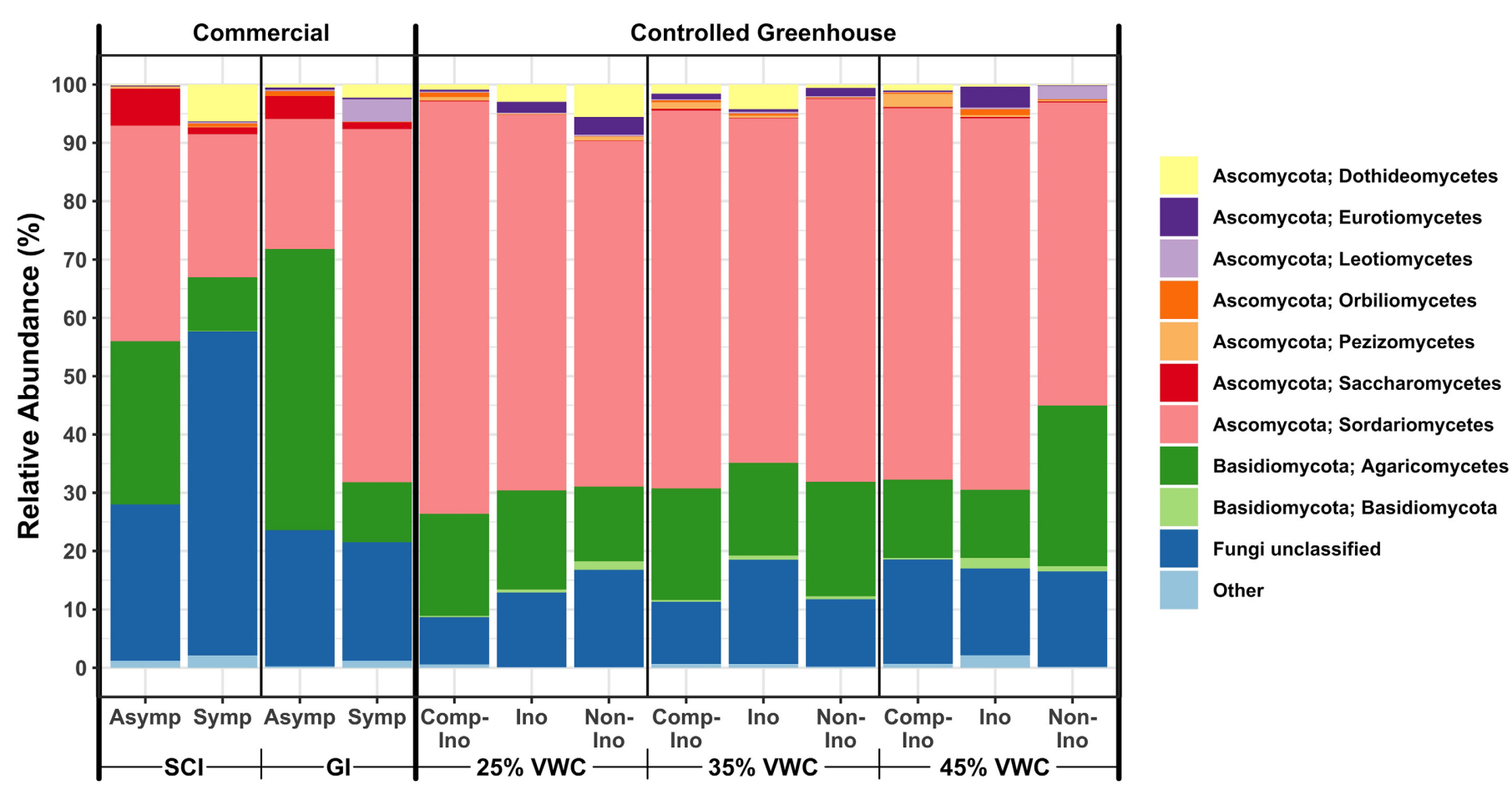

Fig. 2. Commercial: Relative abundance of fungal amplicon sequence variants (ASVs) from roots of symptomatic (Symp) and asymptomatic (Asymp) poinsettia plants in a commercial facility irrigated by grower irrigation (GI, 54\% volumetric water content [VWC]) and sensor-controlled irrigation (SCI, target $45 \%$, actual average $50 \% \mathrm{VWC}$ ). Controlled greenhouse: relative abundance of ASVs from poinsettia roots irrigated in a controlled greenhouse study at 45, 35, and 25\% VWC. Pathogen treatments were Pythium aphanidermatum-inoculated, noninoculated and, inoculated and treated with the plant growth promoter Companion. Plants from the commercial facility were used in the controlled greenhouse trials.

TABLE 1

$\alpha$-Diversity (number of amplicon sequence variants [ASVs] and Shannon and Simpson indices) for the fungal library obtained from the commercial greenhouse study, with roots of poinsettia irrigated under grower irrigation (GI, 54\% volumetric water content [VWC]) and sensor based irrigation ( $\mathrm{SCl}, 45 \%$ target, actual average $50 \% \mathrm{VWC})^{\mathrm{z}}$

\begin{tabular}{llccc}
\hline Irrigation treatment (TRT) & Plant health & Number of ASVs & Shannon & Simpson \\
\hline Grower irrigation (GI) & Asymptomatic & $18 \pm 1.39 \mathrm{a}$ & $1.70 \pm 0.11$ & $0.70 \pm 0.04$ \\
\hline & Symptomatic & $28 \pm 1.20 \mathrm{c}$ & $1.52 \pm 0.18$ & $0.62 \pm 0.07$ \\
\hline Sensor-based irrigation (SCI) & Asymptomatic & $23 \pm 1.81 \mathrm{~b}$ & $1.68 \pm 0.12$ & $1.91 \pm 0.18$ \\
\hline & Symptomatic & $28 \pm 1.66 \mathrm{bc}$ & $0.69 \pm 0.03$ \\
\hline$P$ value among TRT & - & 0.2245 & $0.74 \pm 0.06$ \\
\hline$P$ value among plant health & - & 0.0001 & 0.8669 & 0.2745 \\
\hline Irrigation $\times$ TRT interaction & - & 0.0876 & 0.1853 & 0.959 \\
\hline
\end{tabular}

${ }^{\mathrm{z}}$ Letters represent significantly different distributions as determined by analysis of variance followed by a Tukey's honestly significant difference test. 
results with a confidence ranking of "possible", which were largely assigned as facultative pathogens (i.e., pathotroph-saprotroph). The facultative pathogens Fusarium sp. (genus includes both root rot and wilt pathogens) (Summerell 2019) and P. multirostrata (reported as a root rot as well as a foliar pathogen) (Chobe et al. 2020) had a higher abundance in the symptomatic plant roots under the SCI treatment (Supplementary Fig. S2) than in the other treatments.

Oomycete community composition. After preprocessing and filtering the reads, the oomycete library consisted of 59,222 sequences. Oomycete ITS sequences were only present in 6 of the 40 plant roots sampled; these 6 plants were symptomatic, with 4 plants irrigated under SCI and 2 under GI. The most abundant ASV was identified as Pythium ultimum and had an abundance of 99.3 to $100 \%$ across treatments; sample size was too small to analyze effects of irrigation treatment on sequence abundance.

Controlled greenhouse experiment. After preprocessing and filtering the fungal libraries, we obtained 6,894,471 sequences from all 144 samples processed. For the oomycetes, 435,963 sequences were recovered from 96 of the 144 samples processed. Results of the fungal and oomycete community composition are presented separately below.

Fungal community composition. ASVs belonged to 20 classes, with the Sordariomycetes (62\% average) being the most abundant, followed by Agaricomycetes (18\%), and unclassified fungi (14\%) across all irrigation and pathogen treatments; the additional 17 classes, including Dothideomycetes and Eurotiomycetes, each had an abundance of $<1 \%$ (Fig. 2).

$\alpha$-Diversity and community structure. Based on $\alpha$-diversity analyses, irrigation and pathogen treatment had a significant effect on the number of ASVs $(P=0.02$ and $P<0.0001$, respectively), with four more ASVs at $45 \%$ VWC compared with $25 \%$ VWC. Across all irrigation treatments, noninoculated plants had eight fewer ASVs than inoculated plants. For pathogen treatments, noninoculated plants had eight fewer ASVs than inoculated plants and inoculated plants + Companion. Irrigation and pathogen treatment

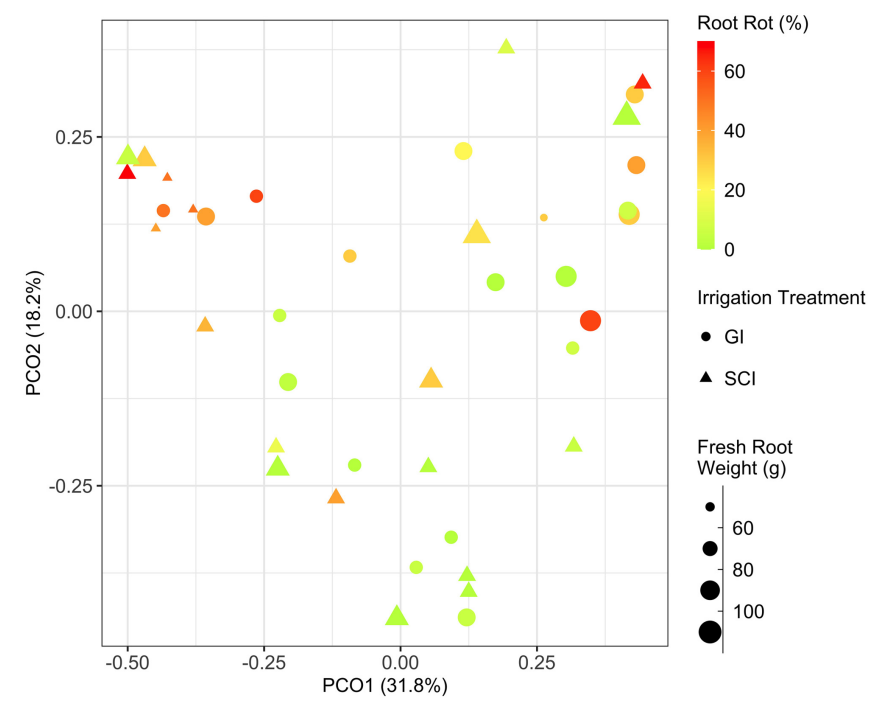

Fig. 3. Principal coordinate (PC) analyses based on a Bray-Curtis dissimilarity matrix of the first two PCs discriminating fungal communities by irrigation treatments (grower irrigation [GI] and sensor-controlled irrigation [SCl]) and plant symptoms. Symbols are color coded by the percentage of root rot in a sample. Symbol size corresponds to the fresh root weight (in grams [g]). Trial conducted on-site at the commercial poinsettia production facility. did not have a significant effect on Shannon or Simpson indices $(P>0.05)$ (Table 2$)$. The relative differences in diversity were $7 \%$ for Shannon (from 1.28 to 1.53 ) and $20 \%$ for Simpson (0.54 to 0.65 ) indices (Table 2). Irrigation or pathogen treatments did not have a significant effect on fungal community associated with poinsettia roots (adonis $P=0.321$ and $P=0.098$, respectively).

Differential abundance analysis. Differential abundance analysis of sequence variants showed that, among irrigation treatments (45, 35, and 25\% VWC), the ASVs classified as P. multirostrata, Plectosphaerella cucumerina, Cladosporium delicatulum, and an unidentified Alternaria sp. had significantly higher relative abundances $(P<0.01)$ at 25 versus $45 \%$ VWC. Comparing ASV abundances among 45 and $35 \%$ VWC irrigation treatments, only Penicillium sp. had a significant increase in relative abundance $(P<$ $0.01)$ in the latter treatment. Based on MDMR analyses, the response variables shoot growth $(P=0.4204)$, root weight $(P=$ $0.3493)$, and disease severity $(P=0.2172)$ did not have an association with the fungal community composition. Comparing pathogen treatments (noninoculated, Pythium aphanidermatum-inoculated, and $P$. aphanidermatum-inoculated + Companion), none of the ASVs were differentially abundant.

Fungal ecological guild diversity. In total, 41 species had FUNGuild assignments of "highly probable" or "probable" and these taxa represented between 53.3 and $70.2 \%$ of fungal communities. The species occurring at the highest abundance $(48 \%$, or 20 of 41) were mostly nonplant pathogens, including saprobes such as Clitopilus sp. and Wallemia sp. (both Basidiomycetes), and Arthrobotrys sp., a putative nematode predator (Niu and Zhang 2011) (1 to 6\% range). The majority of these nonplant pathogens were similarly distributed among all of the irrigation and pathogen treatments (Fig. 5). However, the saprobic taxa Wallemia sp., and Orbiliaceae sp., the nematode-trapping fungus Arthrobotrys conoides, and a Talaromyces sp. (potential pathogen-suppressing beneficial) had a greater abundance in the $45 \%$ VWC treatment versus the $25 \%$ VWC. In contrast, one saprobic species, Clitopilus hobsonii, was more abundant in the $25 \%$ VWC treatment. Approximately $14 \%$ of the species present were classified as plant pathogens, with Plectosphaerella cucumerina (known to cause root and collar rot of horticultural crops) (Carlucci et al. 2012) similarly distributed among all of the irrigation treatments, and Mycosphaerella tassiana (syn. Cladosporium herbarum) (predominantly an aboveground pathogen) significantly more abundant (70\% greater) in the $25 \%$ VWC treatment versus $45 \%$ VWC, and absent in the $35 \%$ VWC treatment. In addition, the fungal and nematode parasite Clonostachys rosea (Xue 2003) was significantly less abundant at $25 \%$ VWC (98\% reduction compared with $45 \%$ VWC), and absent in the mild-irrigation treatment (35\%VWC). Species assigned as facultative pathogens or saprobe-pathotrophs (14\%) and symbiotrophs (11\%) were similarly distributed in all irrigation treatments (Fig. 5).

For species with "possible" FUNGuild assignments, most (62\%) were classified as saprobes, including taxa such as Penicillium sp., Clitopilus sp., and Trichoderma sp. (which can function in pathogen antagonism, beneficial to plants) (Howell 2003; Waqas et al. 2015); or, some species have been reported as plant pathogens (Li Destri Nicosia et al. 2015). Among irrigation treatments, most of the saprobes $(10 \%)$ were present in the reduced irrigation treatment (25\% VWC) compared with the treatments with higher water availability (Supplementary Fig. S3). Species classified as facultative pathogens were the second most abundant (29\%), with Fusarium spp. similarly distributed across the three irrigation treatments, although with higher prevalence among the inoculated plants. The mycoparasite Cladosporium delicatulum (Amanelah Baharvandi and Zafari 2015) and the foliar pathogen Phoma multirostrata 
(likely a saprobe in roots) (Garibaldi et al. 2010) had a 10 and $129 \%$ higher prevalence, respectively, in the reduced irrigation treatment (25\% VWC) than in the well-watered irrigation treatments. Only two ASVs identified as Plectosphaerella spp. (the genus includes many root and collar rot pathogens) were classified as likely root pathogens, and their prevalence was evenly distributed among the irrigation treatments (Supplementary Fig. S3).

Oomycete community composition. Taxa diversity was low, with 36 ASVs identified. Most of the ASVs (15) were classified into eight species, including Phytophthora plurivora, P. cinnamomi, $P$. syringae, $P$. lateralis, P. tentaculata, Pythium ultimum, and $P$. aphanidermatum (different from the ASV of the inoculated strain: ASV_0003), with a relative abundance of $<5 \%$ for each. These eight species are all known root and crown rot pathogens, and have been described causing disease in ornamental crops. Fourteen of the ASVs were classified to the class level as oomycetes, with an average relative abundance of $1.5 \%$. At the genus level, two and four ASVs were classified as Phytophthora spp. and Pythium spp.,
Z-scored RA

$\begin{array}{lllll}-2 & -1 & 0 & 1 & 2\end{array}$

\section{Irrigation Treatment \\ GI \\ $\mathrm{SCl}$}

Trophic Mode

Pathotroph

Saprotroph

Symbiotroph

Pathotroph-Symbiotroph

Saprotroph-Symbiotroph

\section{Guild}

Plant Pathogen

Undefined Saprotroph

Wood Saprotroph

Endophyte

Ericoid Mycorrhizal

Mixed

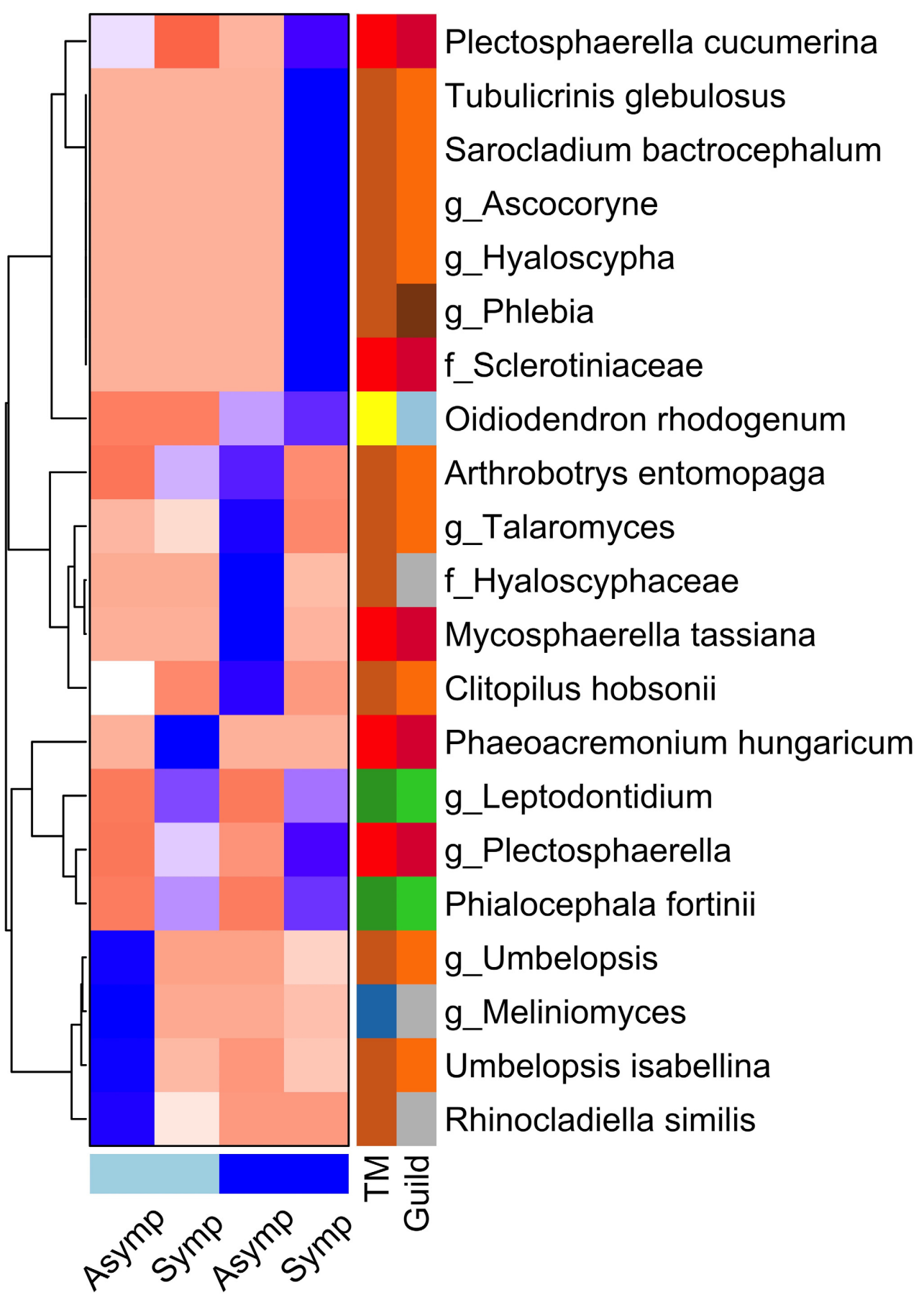

Fig. 4. Heat map of the "highly probable" and "probable" fungal species abundance (z-scored) with assigned trophic mode and guild using FUNGuild (further examined based on literature analysis, as presented in Results), from symptomatic (Symp) and asymptomatic (Asymp) poinsettia roots irrigated under grower irrigation (GI) and sensor-controlled irrigation (SCl) in the trial conducted on-site at the commercial poinsettia production facility. 
respectively, both with a relative abundance of $<1 \%$. The inoculated $P$. aphanidermatum had an average abundance of $70 \%$, and its prevalence was very similar among all of the inoculated treatments (Fig. 6).

Based on $\alpha$-diversity analyses, irrigation and pathogen treatment did not have a significant effect in the number of ASVs or Shannon or Simpson indices $(P>0.05)$ (Table 2). Most of the samples within treatments had only one ASV, with the exception of the noninoculated plants irrigated at $45 \%$ VWC, with an average of three ASVs present. Samples of noninoculated plants irrigated at $35 \%$ VWC did not have any oomycete ASVs. The oomycete community of plants irrigated at $45 \%$ VWC was more diverse $($ Shannon $=0.30$, Simpson $=0.45$ ) compared with the oomycete communities irrigated at $25 \%$ VWC (Shannon $=$ 0.17 , Simpson $=0.52$ ) and at 35\% VWC (Shannon $=0.09$, Simpson $=0.55$ ).

Community structure. Irrigation treatment had a significant effect (adonis $P=0.001$ ) on the oomycete community composition but pathogen treatment did not $(P=0.6515)$ (Fig. 6). Specifically, inoculated plants treated with Companion at $45 \%$ VWC had the greatest number of ASVs $(n=13)$, than all of the other irrigation treatments (6 ASVs on average) (Fig. 6). Pathogenic species, including Phytophthora cinnamomi, P. lateralis, $P$. plurivora, and $P$. syringae, were only present in plants under $45 \% \mathrm{VWC}$, with a mean abundance of $4 \%$ (Fig. 6). For the other irrigation treatments, ASVs assigned as oomycetes, Pythium spp., Pythium ultimum, and

TABLE 2

$\alpha$-Diversity (number of amplicon sequence variants [ASVs] and Shannon and Simpson indices) for fungal and oomycete libraries obtained from the controlled greenhouse study, with roots of poinsettia irrigated at 45,35 , and $25 \%$ volumetric water content (VWC) ${ }^{y}$

\begin{tabular}{|c|c|c|c|c|}
\hline Irrigation, pathogen ${ }^{z}$ & $N$ & Number of ASVs & Shannon & Simpson \\
\hline \multicolumn{5}{|l|}{ Fungal } \\
\hline \multicolumn{5}{|l|}{$45 \%$ VWC } \\
\hline Inoculated (Inoc.) & 16 & $35.37 \pm 2.69 \mathrm{bc}$ & $1.32 \pm 0.11$ & $0.54 \pm 0.04$ \\
\hline Inoc. + Companion & 16 & $33.00 \pm 2.77 \mathrm{bc}$ & $1.51 \pm 0.10$ & $0.63 \pm 0.03$ \\
\hline Noninoculated & 16 & $21.56 \pm 1.76 \mathrm{a}$ & $1.37 \pm 0.11$ & $0.62 \pm 0.04$ \\
\hline Inoc. & 16 & $29.56 \pm 2.17 b$ & $1.49 \pm 0.12$ & $0.63 \pm 0.05$ \\
\hline Inoc. + Companion & 16 & $33.43 \pm 2.89 \mathrm{bc}$ & $1.44 \pm 0.07$ & $0.63 \pm 0.03$ \\
\hline \multicolumn{5}{|l|}{$25 \%$ VWC } \\
\hline Noninoculated & 17 & $25.05 \pm 2.14 a b$ & $1.53 \pm 0.09$ & $0.65 \pm 0.03$ \\
\hline$P$ value among pathogen TRT & - & $<0.0001$ & 0.9807 & 0.6546 \\
\hline Irrigation $\times$ pathogen interaction & - & 0.0067 & 0.3208 & 0.3489 \\
\hline \multicolumn{5}{|l|}{ Oomycete } \\
\hline \multicolumn{5}{|l|}{$45 \%$ VWC } \\
\hline Noninoculated & 1 & $3.00 \pm 0.0$ & $0.71 \pm 0.0$ & $0.39 \pm 0.0$ \\
\hline Inoculated (Inoc.) & 16 & $1.00 \pm 0.15$ & $0.01 \pm 0.01$ & $0.38 \pm 0.12$ \\
\hline Inoc. + Companion & 13 & $1.00 \pm 0.45$ & $0.19 \pm 0.10$ & $0.58 \pm 0.12$ \\
\hline \multicolumn{5}{|l|}{$35 \%$ VWC } \\
\hline Noninoculated & 0 & $0.00 \pm 0.00$ & $0.00 \pm 0.00$ & $0.00 \pm 0.00$ \\
\hline$P$ value among irrigation TRT & - & 0.3365 & 0.1548 & 0.2445 \\
\hline$P$ value among pathogen TRT & - & 0.6784 & 0.3584 & 0.4884 \\
\hline Irrigation $\times$ pathogen interaction & - & 0.5191 & 0.3247 & 0.5152 \\
\hline
\end{tabular}

y Letters represent significantly different distributions as determined by analysis of variance followed by a Tukey's honestly significant difference test.

z Irrigation and pathogen treatments (TRT). 
$P$. aphanidermatum were also present at similar levels. The $P$. aphanidermatum mentioned in the preceding sentence was different from the inoculated isolate (ASV_0003) based on BLAST comparison (Fig. 6).

\section{DISCUSSION}

Previous studies to evaluate how water scarcity-driven changes in irrigation practices influence individual plant pathogens have

\section{Z-scored RA \\ $\begin{array}{lllll}-2 & -1 & 0 & 1 & 2\end{array}$}

\section{Irrigation Treatment}

$25 \%$ VWC

$35 \%$ VWC

$45 \%$ VWC

\section{Trophic Mode}

Pathotroph

Saprotroph

Symbiotroph

Pathotroph-Saprotroph

Pathotroph-Symbiotroph

Saprotroph-Symbiotroph

\section{Guild}

\section{Plant Pathogen}

Undefined Saprotroph

Wood Saprotroph

Endophyte

Ectomycorrhizal

Ericoid Mycorrhizal

Animal Pathogen

Mixed

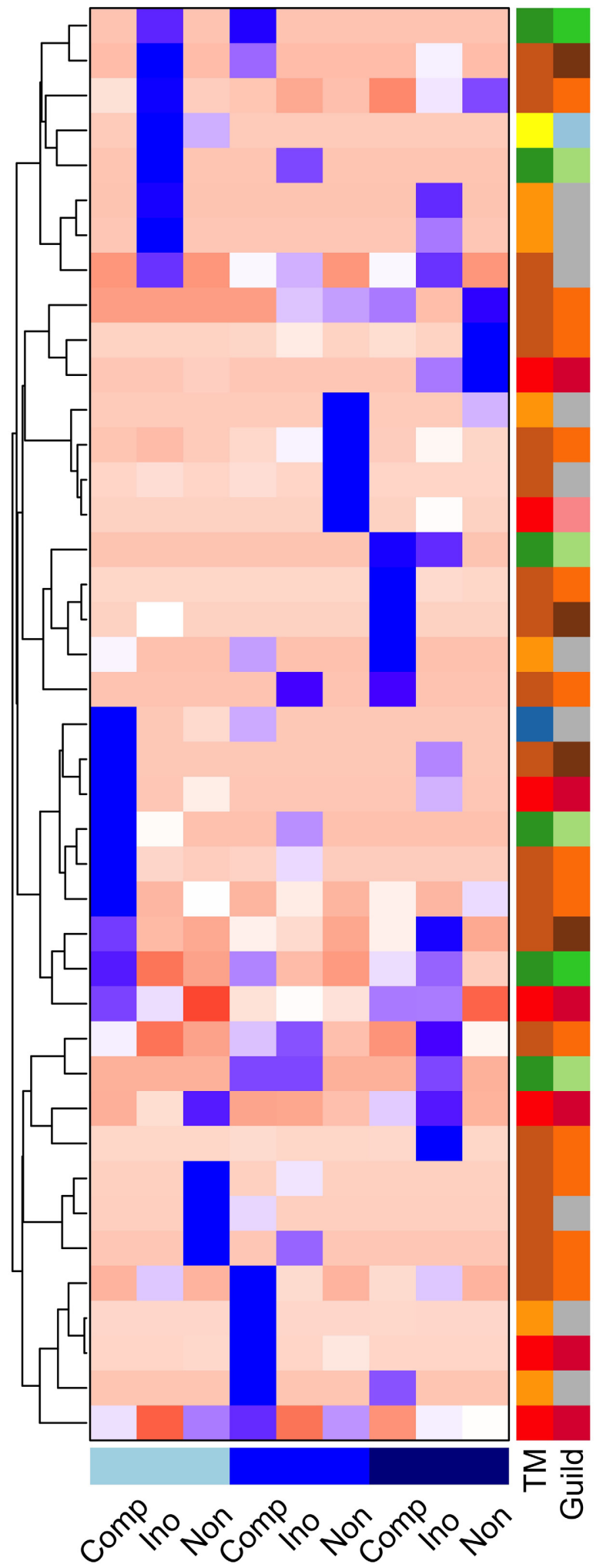

Phialocephala fortinii

Trametes hirsuta

g_Hyaloscypha

Oidiodendron rhodogenum

g_Hysterangium

Rhodotorula paludigena

g_Didymella

g_Leucosporidium

g_Talaromyces

$f$ Lasiosphaeriaceae

Clonostachys rosea

g_Sporobolomyces

Emericellopsis humicola

Rhinocladiella similis

g_Simplicillium

Hydnellum peckii

g_Tetraplosphaeria

g_Phlebia

Exophiala cancerae

Tubulicrinis glebulosus

g_Meliniomyces

Junghuhnia nitida

Mycosphaerella tassiana

Leucogaster citrinus

Sarocladium bactrocephalum

Clitopilus hobsonii

f_Orbiliaceae

g_Leptodontidium

Plectosphaerella cucumerina

Arthrobotrys conoides

Tuber melanosporum

f Sclerotiniaceae

g-Wallemia

Nigrospora oryzae

f_Hyaloscyphaceae

g_Umbelopsis

Mucor strictus

Exophiala equina

Phaeoacremonium hungaricum

f Mycosphaerellaceae

g_Plectosphaerella

Fig. 5. Heat map of the "highly probable" and "probable" fungal species abundance (z-scored) with assigned trophic mode and guild (using FUNGuild) (further examined based on literature analysis, as presented in Results), from poinsettia roots irrigated at 45 , 35 , and $25 \%$ volumetric water content (VWC). Pathogen treatment consisted of: Pythium aphanidermatum-inoculated plants (Ino), noninoculated (Non), and inoculated and treated with the plant growth promoter Companion (Comp) conducted in controlled greenhouse trials using plants from the commercial facility. 
demonstrated that reductions in irrigation inputs can increase the risk of root pathogen infection and disease development (Choi et al. 2013; Del Castillo Múnera et al. 2019a; Lima et al. 2019; Swett 2020). Understanding the effect of reduced irrigation on endophytic root microbiome community composition provides a broader understanding of which pathogen groups are facilitated and suppressed by reduced irrigation, as well as potential indirect effects of beneficial microbes. Studies of irrigation-dependent systems in particular, including containerized and covered production, are critical to help demystify risks of irrigation adaptations. Although single-pathogen studies are useful, community-scale studies offer the opportunity to examine broader effects on plant-health-mediating organisms, including impacts on organisms which interact with pathogens (e.g., mycoparasites) and effects on cryptic members of the pathogen community.

This study suggests that minor reductions in irrigation applied to poinsettia in a commercial setting did not have large effects on the fungal composition: it slightly increased $\alpha$ diversity but had no effect in the fungal community structure. Plant health status had a significant effect on the fungal community structure. Specifically, Fusarium, a genus that encompasses many root and crown rot pathogens (Summerell 2019), and Phoma multirostrata, reported as a root and foliar pathogen (Chobe et al. 2020; Garibaldi et al. 2010) were more abundant in symptomatic plants under the SCI (54.2\% VWC), which deployed $8.5 \%$ less water than the GI treatment $(50.2 \%$ VWC). When further reductions in irrigation were applied to a poinsettia crop, irrigation treatments $(45,35$, and $25 \%$ VWC) did not have a significant effect in the fungal community structure, richness, and evenness; however, the abundance of P. multirostrata and taxa in the Fusarium genus significantly increased in roots of plants irrigated at $25 \%$ VWC compared with the wellwatered (45\% VWC) and mild-irrigation (35\% VWC) treatments. These results are consistent with other studies of root rot fungal pathosystems, which indicate that reducing irrigation inputs can increase the risk of root rot and wilt pathogens, including several Fusarium pathogens (Parsons and Munkvold 2010; Ragazzi et al. 1995; Ristaino 1991; Swett 2020).

Similar to our findings, Barnard et al. (2013) did not detect changes in the fungal community composition of California grasslands under dry-down or wet-up conditions; however, the relative abundance of Sordariomycetes, Eurotiomycetes, and Lecanoromycetes increased under dry-down periods. In our study, species of Sordariomycetes were the most abundant fungal group, similarly distributed among all irrigation treatments; Eurotiomycetes and Lecanoromycetes had a low abundance (1\%) in all treatments. In agricultural settings, Dangi et al. (2016) found that deficit irrigation applied during 3 months compared with full irrigation did not have an effect in the soil microbial biomass of peach orchards but irrigation methods (furrow, micro-sprinkler, and surface drip) did.

The lack of an effect on the fungal community structure in poinsettia roots when applying reduced irrigation may have several explanations. Fungi have the ability to withstand disturbance (in this case, reduced water availability). They can increase carbon and nitrogen retention from the soil (De Vries et al. 2012) and use these stores later during stress events, making them more resistant to change. Additionally, fungal morphology may have the ability to cross soil or substrate pores to access water (Barnard et al. 2013; De Vries et al. 2012). Alternatively, the duration of the reduced irrigation treatments (10 weeks in the commercial study and 6 weeks in the controlled greenhouse study) and the reductions in the VWC applied in each treatment were perhaps not long or low enough to experience drastic soil moisture changes that would perhaps have a more significant effect on the endophyte fungal composition of poinsettia roots under reduced levels of irrigation. Finally, the timing in which reduced irrigation was applied relative

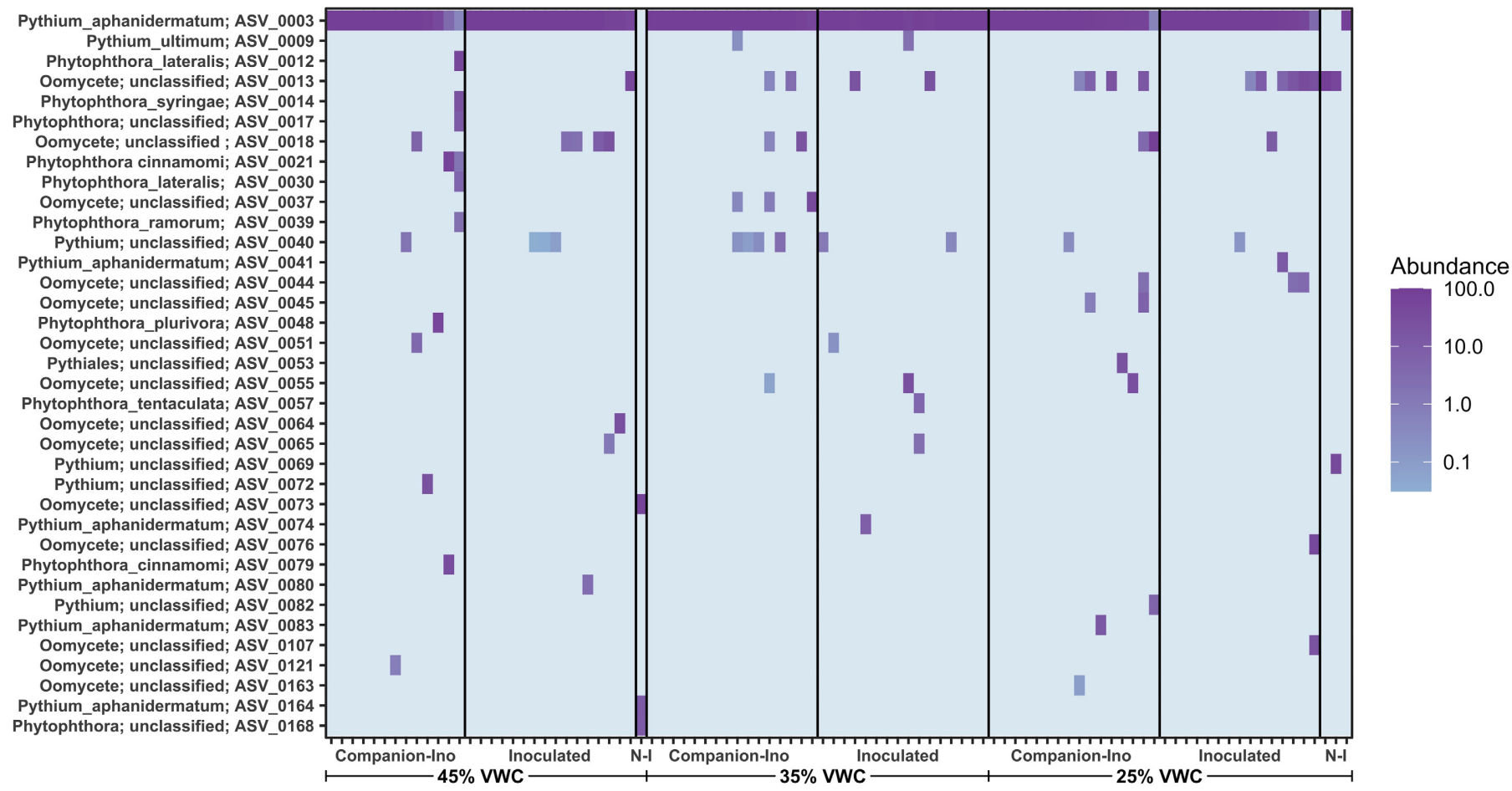

Fig. 6. Heat map of oomycete species abundance from poinsettia roots irrigated at 45,35 , and $25 \%$ volumetric water content (VWC). Pathogen treatment consisted of: Pythium aphanidermatum-inoculated plants (Inoculated), noninoculated (N-I), and inoculated and treated with the plant growth promoter Companion (Companion-Ino), conducted in controlled greenhouse trials using plants from the commercial facility. No oomycetes were found in the noninoculated treatment irrigated at $35 \%$ VWC. 
to poinsettia development is a factor to consider when determining treatment effects on endophytic fungal communities. In this study, 11-week-old plants were assessed, and the seedling stage may be important for establishment of endophytic fungal communities (Kim and Lee 2021; Shahzad et al. 2018). Future studies applying reduced irrigation at the seedling stage should be considered, to determine whether there are greater shifts in fungal endophytic communities.

Long-term studies have shown that fungal communities in naturally managed ecosystems are affected by changes in irrigation patterns over longer periods of time (Lüneberg et al. 2019; Zheng et al. 2017). During a 4-year study, Zheng et al. (2017) showed that the fungal community composition of Eucalyptus roots and soil in Australian forests significantly changed when additional (1,000 mm/year) irrigation + ambient rainfall were applied, compared with rainfall only. Specifically, additional irrigation increased the presence of ectomycorrhizal fungi in root samples but decreased its abundance in soil. Conversely, in our study, ectomycorrhizal fungi were present in the lowest irrigation treatment (25\%VWC) but not in the higher irrigation treatments. This may be due to chance alone or indicate potential for host recruitment of mycorrhizae (via exudates or other mechanisms) under water stress (Zheng et al. 2017).

Fungal diversity was moderate, and Simpson indices were similar to those of fungal communities from Rhododendron plants grown in containerized nursery production (Foster et al. 2020). Interestingly, plant health status in the commercial study had a greater effect at increasing fungal richness and diversity (Shannon and Simpson indices) than irrigation treatment. Surprisingly, when further reductions in irrigation were applied, the fungal diversity and evenness was the same for all irrigation and pathogen treatments. Although there were not changes in the fungal diversity at lower irrigation inputs, differential abundance analyses showed an increase in abundance of some facultative pathogens that may increase the disease risk under a scenario of reduced water availability. This effect was consistent in presence of pathogens and the biological control Companion.

In the commercial greenhouse study, symptomatic plants had $55 \%$ more ASVs than asymptomatic ones, and abundance increased in plants with greater root rot (MDMR analyses). $P$. multirostrata was recovered at higher incidence in symptomatic roots. It has been reported as a foliar pathogen of fuchsia (Garibaldi et al. 2010) and coriander (Golzar et al. 2015). In addition, taxa identified only to the genus level included Fusarium (Summerell 2019), Curvularia (Manamgoda 2015), and Plectosphaerella (Li et al. 2017; Xu et al. 2014; Yang et al. 2018). For these ASVs, further analysis into species identity is needed to provide insight into whether or not these are potentially pathogenic members of the community, because all genera contain diverse species with various life history strategies. For instance, diverse Fusarium oxysporum subspecies (designated formae speciales) are capable of causing wilt of various greenhouse crops (Gullino et al. 2012) but there are also nonpathogenic strains that can function as endophytic mutualists to deter plant-parasitic nematodes (Sikora et al. 2008). In addition, pathogenicity experiments with each of these species need to be carried out, because there are many species in these genera which vary in ecological functions across crops. For example, the species Plectosphaerella cucumerina has been reported as a root rot pathogen of greenhouse-grown tomato (Xu et al. 2014) and wild rocket (Garibaldi et al. 2010) but can also function as a biocontrol, with nematophagous activity in potato (Jacobs 2000). It is important to note that the oomycete Pythium ultimum was recovered from 6 of the 10 symptomatic plants per treatment evaluated; unlike the aforementioned fungi, P. ultimum is a known poinsettia pathogen causing root rot in greenhouses in the United States (Del Castillo Múnera et al. 2019c; Lookabaugh and Shew 2015; Moorman et al. 2002). This may indicate that P. ultimum was a facilitator of secondary pathogens.

In the controlled greenhouse study, with further reductions in irrigation, we observed that the relative abundance of Phoma multirostrata and Alternaria sp., classified as pathothrophs, and Plectosphaerella cucumerina, assigned as a pathogen with root rot abilities in other crops (Elmer et al. 2020), significantly increased when irrigation was reduced from 45 to $25 \%$ VWC. As emphasized above, because there are (to our knowledge) no documented occurrences of Phoma multirostrata, Plectosphaerella cucumerina, or Alternaria spp. causing root rot of poinsettia, pathogenicity studies are required to better understand impacts of irrigation reductions in the context of pathogenic members of the rhizosphere community.

These results may imply that, at least in this production system, more extreme reductions in irrigation favor the presence of facultative pathogens, or that the change in moisture may facilitate a shift from a biotrophic or saprotrophic to a necrotrophic state. If host plants are experiencing stress due to low water availability, this may facilitate pathogen infection and exacerbate disease that may not occur under well-watered conditions, as has been described for the phenomenon of pathogen predisposition (Bostock et al. 2014; Swett 2020). Interestingly, there were very few changes from 45 to $35 \%$ VWC, the exception being Penicillium sp., which had higher abundance at $35 \%$ VWC. At the fungal community level, this indicates that reducing irrigation to $35 \%$ VWC can mitigate disease risk. In our previous study (Del Castillo Múnera et al. 2019b), water reductions to $35 \%$ VWC were similarly possible without affecting plant growth through either direct physiological effects on the plant or indirect effects on disease from the pathogen Pythium aphanidermatum. Taken together, these studies indicate that there is a threshold irrigation level at or above which reductions in water usage do not compromise plant health in the presence of pathogens. Because this threshold level will be specific to the system (crop, substrate, and so on), threshold risk levels under reduced irrigation for other crops and production systems would need to be examined in a system-specific context. In terms of water usage, we found that the collaborating commercial greenhouse could safely reduce water, with savings up to $23 \%$ (Del Castillo Múnera et al. 2019b).

Effects on nonpathogens, with emphasis on potential pathogen-modulating organisms. In evaluating effects on nonpathogens, we found that reducing irrigation also increased occurrence of fungal parasites or antagonists which may have possible roles in pathogen suppression, including the mycoparasites Clonostachys rosea and Cladosporium delicatulum. ASVs aligning with Trichoderma and Penicillium may also fall into this group, because these genera include a large number of species with documented disease-suppressing effects (Howell 2003; Torres et al. 2017; Waqas et al. 2015; Xue 2003), as well as other benefits. Nevertheless, it is important to note that these genera also include species capable of causing root disease in other hosts (Li Destri Nicosia et al. 2015). To better determine whether these organisms are beneficial and, if so, study irrigation reduction effects in greater detail, identification to species level and functional analysis as mycoparasites, as well as confirmation of nonpathogenic abilities on poinsettia, are both required.

Effect of $\mathrm{P}$. aphanidermatum and $\mathrm{B}$. subtilis in fungal and oomycete community composition. Pathogen treatment, which consisted of $P$. aphanidermatum inoculum, and the addition of the biological control B. subtilis GB03 to some inoculated plants did not have an effect on the fungal community structure. Nevertheless, based on the ecological roles assigned by FUNguild, the species assigned as saprobes were more abundant when plants were irrigated 
at $25 \% \mathrm{VWC}$ in all pathogen treatments. Based on our previous study, Pythium root rot was more severe in plants irrigated at $25 \%$ VWC; thus, the higher abundance of saprobes may be explained by more available necrotic root tissue that saprobes can feed on. The biological control did not have any effect at reducing root rot (Del Castillo Múnera et al. 2019b), and there was no indication of antagonism against other possible pathogens of any fungal taxa in poinsettia roots. Unlike the biological control used in our study, there are reports of synthetic fungicides that reduce the diversity of fungal communities associated with wheat (Karlsson et al. 2014) and organic amendments that change the soil microbial activity when added (Yao et al. 2006). It is possible that the biological control added in our study had an effect in the bacterial community but this would need to be evaluated. Additionally, it would be interesting to evaluate whether other microorganisms used as biocontrols are able to shift community composition and favor the abundance of beneficial microorganisms to greenhouse crops under reducedirrigation scenarios, unlike the biological control added in this study.

Effect of reduced irrigation on oomycete community. Although oomycetes are a recurrent challenge for the collaborating nursery, and are common contaminants in their recycled water system (Beaulieu et al. 2017, 2018; Del Castillo Múnera and Swett 2017; Ristvey et al. 2019), oomycete sequences represented only $6 \%$ of the total sequences $(7,935,004)$ recovered from poinsettia roots, and oomycete diversity and abundance in the rhizosphere was consistently low. These results are consistent with similar studies which have found low oomycete abundance in other nursery crops (Foster et al. 2020). This likely reflects the active efforts on the part of the producer to control oomycete pathogens (Ristvey et al. 2019), including peat-perlite substrates instead of soil (which they believe to be oomycete-suppressive), irrigation regimes aimed at suppressing oomycete pathogens, slow sand filtration to remove waterborne microbes (predominantly oomycetes) from recycled irrigation, and a heavy oomycete-targeted chemical management program. The latter includes the application of etridiazole and cyazofamid starting in early propagation stages through the end of the crop cycle. These chemistries target oomycetes and have been shown to be effective at controlling Pythium and Phytophthora spp. in ornamental production (Gutiérrez et al. 2012; Lookabaugh and Shew 2015; Moorman and Kim 2004).

Reductions in irrigation had a significant effect in the oomycete community structure. Specifically, there was a higher oomycete diversity and abundance in the well-watered treatment (45\% VWC) as compared with the treatments with lower water availability. The species Phytophthora cinnamomi, P. syringae, P. lateralis, and $P$. plurivora present in poinsettia roots irrigated at $45 \% \mathrm{VWC}$ have been reported as pathogens of ornamental crops (Beaulieu et al. 2017; Benson et al. 2002; Leonberger et al. 2013; Parke et al. 2014; Weiland et al. 2018). Our findings support the extensive literature (Bryla and Linderman 2007; Granke et al. 2009; Hausbeck and Lamour 2004; Parke et al. 2014; Weiland 2011) showing that high water availability favors oomycete presence and abundance. In our study, when plants were irrigated at $35 \%$ VWC, only six ASVs were present, including Pythium ultimum, P. aphanidermatum (different from the one inoculated), and Pythium sp. Interestingly, no ASVs were recovered from the noninoculated plants irrigated at $35 \%$ VWC. These results indicate that irrigation practices which reduce soil moisture (SCI) will be suppressive to diseases caused by oomycete pathogens, and that mild reductions in irrigation (to $35 \%$ VWC) can be implemented as a cultural practice to reduce oomycete abundance and, consequently, reduce the risk of root rot infections.

Similar to fungal community diversity outcomes, pathogen treatment (inoculated, inoculated + biocontrol, or noninoculated) did not have an effect on oomycete community composition, indicating that $P$. aphanidermatum is not a competitor or facilitator of other oomycete species and, thus, not affecting oomycete abundance. It has been shown that multiple oomycete species coexist within one host (Rojas et al. 2017; Rooney-Latham et al. 2019; Schwingle et al. 2007), without affecting their ability to cause disease. The lack of effect of the biocontrol B. subtilis GB03 in the oomycete community composition can account for the inability to counter Pythium root rot (Del Castillo Múnera et al. 2019b), implying that it did not act as an antagonist to reduce oomycete abundance, thus not affecting the community composition.

We tentatively identified one ASV as Phytophthora ramorum and another as $P$. tentaculata, (relative abundance lower than $0.3 \%$ ), which are both of regulatory concern in the United States (Rooney-Latham et al. 2019). It is important to note that, with the ITS1 sequence, it is not possible to discern between species within a clade (Foster et al. 2020; Redekar et al. 2019). The ITS sequence assigned as $P$. tentaculata can also share $100 \%$ identity with the species in clade $1 \mathrm{~b}, P$. iranica and $P$. clandestina. $P$. ramorum ITS sequences also shared similarity with those of $P$. lateralis and $P$. hibernalis. In order to determine whether these quarantine pathogens were present in the nursery, further studies are needed, including pathogen isolation and use of more molecular markers. This highlights both the potential use of community-scale approaches as well as challenges and risks in regulatory plant pathology.

Implications to management. We demonstrated that, although the microbial communities are not largely affected by reducing irrigation inputs to the lowest irrigation levels, the presence of facultative fungal pathogens increased. Interestingly, reductions at $35 \%$ VWC did not favor or increase the abundance of facultative pathogens that, under drought stress conditions, could cause disease. Additionally, we found that reduced irrigation (up to $35 \%$ VWC), in addition to being an alternative to decrease the water consumption in commercial nurseries, can be used as a management strategy to reduce oomycete abundance and diversity.

Overall, these studies indicate that there may be a need to improve management of diseases that are enhanced by watersavings practices. This could include use of more pathogen-resistant and drought-tolerant cultivars, investigating the effect of the timing at which reduced irrigation is applied, and improvement of cultural practices such as enhanced sanitation and pesticide use (Swett 2020).

\section{ACKNOWLEDGMENTS}

We thank Jennifer Parke, Neelam R. Redekar, and Joyce L. Eberhart for technical assistance provided at Oregon State University; cooperating growers; and Elizabeth Prinkey for experimental assistance.

\section{LITERATURE CITED}

Abarenkov, K., Nilsson, R. H., Larsson, K. H., Alexander, I. J., Eberhardt, U., Erland, S., Høiland, K., Kjøller, R., Larsson, E., Pennanen, T., Sen, R., Taylor, A. F. S., Tedersoo, L., Ursing, B. M., Vrålstad, T., Liimatainen, K., Peintner, U., and Kõljalg, U., 2010. The UNITE database for molecular identification of fungi-Recent updates and future perspectives. New Phytol. 186:281-285.

Altschul, S. F., Gish, W., Miller, W., Myers, E. W., and Lipman, D. J. 1990. Basic local alignment search tool. J. Mol. Biol. 215:403-410.

Amanelah Baharvandi, H., and Zafari, D. 2015. Identification of Cladosporium delicatulum as a mycoparasite of Taphrina pruni. Arch. Phytopathol. Plant Prot. 48:688-697.

Andrews, S. 2010. FastQC: A quality control tool for high throughput sequence data. https://www.bioinformatics.babraham.ac.uk/projects/fastqc/

Barnard, R. L., Osborne, C. A., and Firestone, M. K. 2013. Responses of soil bacterial and fungal communities to extreme desiccation and rewetting. ISME J. 7:2229-2241. 
Beaulieu, J., Del Castillo Múnera, J., Delgado, C., and Swett, C. L. 2018. Enabling recycled water use: The diversity and management of cryptic oomycete pathogens in recycled irrigation water in Mid-Atlantic nurseries. In: Int. Congr. Plant Pathol. (ICPP) 2018: Plant Health in A Global Economy.

Beaulieu, J., Ford, B., and Balci, Y. 2017. Genotypic diversity of Phytophthora cinnamomi and P. plurivora in Maryland's nurseries and mid-Atlantic forests. Phytopathology 107:769-776.

Benson, D. M., Hall, J. L., Moorman, G. W., Daughtrey, M. L., Chase, A. R., and Lamour, K. H. 2002. The history and diseases of poinsettia, the Christmas flower. Plant Health Prog. 3:18.

Bostock, R. M., Pye, M. F., and Roubtsova, T. V. 2014. Predisposition in plant disease: Exploiting the nexus in abiotic and biotic stress perception and response. Annu. Rev. Phytopathol. 52:517-549.

Bryla, D. R., and Linderman, R. G. 2007. Implications of irrigation method and amount of water application on Phytophthora and Pythium infection and severity of root rot in highbush blueberry. HortScience 42:1463-1467.

Callahan, B. J., Mcmurdie, P. J., Rosen, M. J., Han, A. W., Johnson, A. J. A., and Holmes, S. P. 2016. dada2: High-resolution sample inference from Illumina amplicon data. Nat. Methods 13:581-583.

Carlucci, A., Raimondo, M. L., Santos, J., and Phillips, A. J. L. 2012. Plectosphaerella species associated with root and collar rots of horticultural crops in southern Italy. Persoonia Mol. Phylogeny Evol. Fungi 28:34-48.

Chobe, D. R., Tarafdar, A., Chandran, U. S. S., Sudharani, and Sharma, M. 2020. First report of Ectophoma multirostrata causing root rot in chickpea. Plant Dis. 104:1866-1866.

Choi, H. K., Iandolino, A., Da Silva, F. G., and Cook, D. R. 2013. Water deficit modulates the response of Vitis vinifera to the Pierce's disease pathogen Xylella fastidiosa. Mol. Plant-Microbe Interact. 26:643-657.

Connor, R. 2015. The United Nations World Water Development Report 2015: Water for a Sustainable World. UNESCO Publishing, Paris, France.

Costa, J. M., Ortuño, M. F., and Chaves, M. M. 2007. Deficit Irrigation as a strategy to save water: Physiology and potential application to horticulture. J. Integr. Plant Biol. 49:1421-1434.

Dangi, S. R., Zhang, H., Wang, D., Gerik, J., and Hanson, B. D. 2016. Soil microbial community composition in a peach orchard under different irrigation methods and postharvest deficit irrigation. Soil Sci. 181:208-215.

De Vries, F. T., Liiri, M. E., Bjørnlund, L., Bowker, M. A., Christensen, S., Setälä, H. M., and Bardgett, R. D. 2012. Land use alters the resistance and resilience of soil food webs to drought. Nat. Clim. Change 2: 276-280.

Del Castillo Múnera, J., Belayneh, B., Lea-Cox, J., and Swett, C. L. 2019a. Effects of set-point substrate moisture control on oomycete disease risk in containerized annual crops based on the tomato-Phytophthora capsici pathosystem. Phytopathology 109:1441-1452.

Del Castillo Múnera, J., Belayneh, B., Ritsvey, A., Koivunen, E. E., Lea-Cox, J., and Swett, C. L. 2019b. Enabling adaptation to water scarcity: Identifying and managing root disease risks associated with reducing irrigation inputs in greenhouse crop production-A case study in poinsettia. Agric. Water Manage. 226:105737.

Del Castillo Múnera, J., and Hausbeck, M. K. 2016. Characterization of Pythium species associated with greenhouse floriculture crops in Michigan. Plant Dis. 100:569-576.

Del Castillo Múnera, J., Quesada-Ocampo, L. M., Rojas, A., Chilvers, M. I., and Hausbeck, M. K. 2019c. Population structure of Pythium ultimum from greenhouse floral crops in Michigan. Plant Dis. 103:859-867.

Del Castillo Múnera, J., and Swett, C. L. 2017. First report of Pythium aphanidermatum causing root rot and decline of poinsettia in Maryland. Plant Dis. 101:1556-1556.

dos Santos, T. P., Lopes, C. M., Lucília Rodrigues, M., de Souza, C. R., Maroco, J. P., Pereira, J. S., Silva, J. R., and Chaves, M. M. 2003. Partial rootzone drying: Effects on growth and fruit quality of field-grown grapevines (Vitis vinifera). Funct. Plant Biol. 30:663-671.

Elliott, J., Deryng, D., Müller, C., Frieler, K., Konzmann, M., Gerten, D., Glotter, M., Flörke, M., Wada, Y., Best, N., Eisner, S., Fekete, B. M., Folberth, C., Foster, I., Gosling, S. N., Haddeland, I., Khabarov, N., Ludwig, F., Masaki, Y., Olin, S., Rosenzweig, C., Ruane, A. C., Satoh, Y., Schmid, E., Stacke, T., Tang, Q., and Wisser, D. 2014. Constraints and potentials of future irrigation water availability on agricultural production under climate change. Proc. Natl. Acad. Sci. U.S.A. 111:3239-3244

Elmer, W., Li, D. W., Yavuz, S., Madeiras, A., and Schultes, N. 2020. Heuchera root rot, a new disease for Plectosphaerella cucumerina. J. Phytopathol. 168:56-62.

Erwin, D., and Ribeiro, O. 1996. Phytophthora Diseases Worldwide. American Phytopathological Society, St. Paul, MN.
Falkenmark, M. 2013. Growing water scarcity in agriculture: Future challenge to global water security. Philos. Trans. R. Soc. A Math. Phys. Eng. Sci. 371:20120410.

Felsmann, K., Baudis, M., Gimbel, K., Kayler, Z. E., Ellerbrock, R., Bruehlheide, H., Bruckhoff, J., Welk, E., Puhlmann, H., Weller, M., Gessler, A., and Ulrich, A. 2015. Soil bacterial community structure responses to precipitation reduction and forest management in forest ecosystems across Germany. PLoS One 10:e0122539.

Fierer, N., Schimel, J. P., and Holden, P. A. 2003. Influence of dryingrewetting frequency on soil bacterial community structure. Microb. Ecol. 45: 63-71.

Fiske, I. J., and Chandler, R. B. 2011. Unmarked: An R package for fitting hierarchical models of wildlife occurrence and abundance. J. Stat. Softw. 43:1-23.

Foster, Z. S. L., Weiland, J. E., Scagel, C. F., and Grünwald, N. J. 2020. The composition of the fungal and oomycete microbiome of rhododendron roots under varying growth conditions, nurseries, and cultivars. Phytobiomes J. 4:156-164.

Fulcher, A., LeBude, A. V., Owen, J. S., White, S. A., and Beeson, R. C. 2016. The next ten years: Strategic vision of water resources for nursery producers. HortTechnology 26:121-132.

Gardes, M., and Bruns, T. D. 1993. ITS primers with enhanced specificity for basidiomycetes-Application to the identification of mycorrhizae and rusts. Mol. Ecol. 2:113-118.

Garibaldi, A., Gilardi, G., and Gullino, M. L. 2010. First report of leaf spot caused by Phoma multirostrata on Fuchsia $\times$ hybrida in Italy. Plant Dis. 94:382.

Golzar, H., Lanoiselet, V., Wang, C., Tan, Y. P., and Shivas, R. G. 2015. First report of Phoma multirostrata in Australia. Australas. Plant Dis. Notes. 10: $1-2$.

Granke, L. L., Windstam, S. T., Hoch, H. C., Smart, C. D., and Hausbeck, M. K. 2009. Dispersal and movement mechanisms of Phytophthora capsici sporangia. Phytopathology 99:1258-1264.

Gu, Z., Eils, R., and Schlesner, M. 2016. Complex heatmaps reveal patterns and correlations in multidimensional genomic data. http://www.bioconductor. org/packages/devel/bioc/html/ComplexHeatmap.html

Gullino, M. L., Katan, J., and Garibaldi, A. 2012. Fusarium Wilts of Greenhouse Vegetable and Ornamental Crops. American Phytopathological Society, St. Paul, MN.

Gutiérrez, W., Melton, T., and Mila, A. 2012. Pythium root rot of flue-cured tobacco seedlings produced in greenhouses: Factors associated with its occurrence and chemical control. Plant Health Prog. 13:7.

Halo, B. A., Al-Yahyai, R. A., Maharachchikumbura, S. S. N., and Al-Sadi, A. M. 2019. Talaromyces variabilis interferes with Pythium aphanidermatum growth and suppresses Pythium-induced damping-off of cucumbers and tomatoes. Sci. Rep. 9:11255.

Hausbeck, M. K., and Lamour, K. H. 2004. Phytophthora capsici on vegetable crops: Research progress and management challenges. Plant Dis. 88: 1292-1303.

Howell, C. R. 2003. Mechanisms employed by Trichoderma species in the biological control of plant diseases: The history and evolution of current concepts. Plant Dis. 87:4-10.

Jacobs, H. 2000. Development of a Fungal Biological Control Agent for Potato Cyst Nematodes in Jersey. University of Bedfordshire, Luton, England.

Karlsson, I., Friberg, H., Steinberg, C., and Persson, P. 2014. Fungicide effects on fungal community composition in the wheat phyllosphere. PLoS One 9:111786.

Kim, H., and Lee, Y. H. 2021. Spatiotemporal assembly of bacterial and fungal communities of seed-seedling-adult in rice. Front. Microbiol. 12:708475.

Lamm, A. J., Warner, L. A., Taylor, M. R., Martin, E. T., White, S., and Fisher, P. 2017. Diffusing water conservation and treatment technologies to nursery and greenhouse growers. J. Int. Agric. Ext. Educ. 24:105-119.

Lamm, A. J., Warner, L. A., Tidwell, A., Lamm, K. W., Fisher, P. R., and White, S. 2019. Testing an adoption decision-making model of nursery and greenhouse growers' water reuse in the United States. Water 11:2470.

Leonberger, A. J., Speers, C., Ruhl, G., Creswell, T., and Beckerman, J. L. 2013. A survey of Phytophthora spp. in Midwest nurseries, greenhouses, and landscapes. Plant Dis. 97:635-640.

Li Destri Nicosia, M. G., Mosca, S., Mercurio, R., and Schena, L. 2015. Dieback of Pinus nigra seedlings caused by a strain of Trichoderma viride. Plant Dis. 99:44-49.

Li, P. L., Chai, A. L., Shi, Y. X., Xie, X. W., and Li, B. J. 2017. First report of root rot caused by Plectosphaerella cucumerina on cabbage in China. Mycobiology 45:110-113. 
Lima, L. K. S., Jesus, O. N., Soares, T. L., Oliveira, S. A. S., Haddad, F., and Girardi, E. A. 2019. Water deficit increases the susceptibility of yellow passion fruit seedlings to Fusarium wilt in controlled conditions. Sci. Hortic. (Amsterdam). 243:609-621.

Lookabaugh, E. C., Kerns, J. P., Cubeta, M. A., and Shew, B. B. 2018. Fitness attributes of Pythium aphanidermatum with dual resistance to mefenoxam and fenamidone. Plant Dis. 102:1938-1943.

Lookabaugh, E. C., and Shew, B. B. 2015. Mefenoxam sensitivity, aggressiveness, and identification of Pythium species causing root rot on floriculture crops in North Carolina. Plant Dis. 99:1550-1558.

Lüneberg, K., Schneider, D., Brinkmann, N., Siebe, C., and Daniel, R. 2019. Land use change and water quality use for irrigation alters drylands soil fungal community in the Mezquital Valley, Mexico. Front. Microbiol. 10:1220.

MacDonald, J. 1982. Effect of salinity stress on the development of Phytophthora root rot of chrysanthemum. Phytopathology 72:214-219.

Manamgoda, D. S. 2015. A taxonomic and phylogenetic re-appraisal of the genus Curvularia (Pleosporaceae): Human and plant pathogens. Phytotaxa 212:175-198.

Martin, M. 2011. Cutadapt removes adapter sequences from high-throughput sequencing reads. EMBnet.journal 17:10-12.

McArtor, D. B., Lubke, G. H., and Bergeman, C. S. 2017. Extending multivariate distance matrix regression with an effect size measure and the asymptotic null distribution of the test statistic. Psychometrika 82:1052-1077.

McMurdie, P. J., and Holmes, S. 2013. phyloseq: An R package for reproducible interactive analysis and graphics of microbiome census data. PLoS One 8:e61217.

Moorman, G. W., Kang, S., Geiser, D. M., and Kim, S. H. 2002. Identification and characterization of Pythium species associated with greenhouse floral crops in Pennsylvania. Plant Dis. 86:1227-1231.

Moorman, G. W., and Kim, S. H. 2004. Species of Pythium from greenhouses in Pennsylvania exhibit resistance to propamocarb and mefenoxam. Plant Dis. 88:630-632.

Nguyen, N. H., Song, Z., Bates, S. T., Branco, S., Tedersoo, L., Menke, J., and Kennedy, P. G. 2016. FUNGuild: An open annotation tool for parsing fungal community datasets by ecological guild. Fungal Ecol. 20:241-248.

Niu, X. M., and Zhang, K. Q. 2011. Arthrobotrys oligospora: A model organism for understanding the interaction between fungi and nematodes. Mycology 2:59-78.

Oksanen, J., Blanchet, F. G., Friendly, M., Kindt, R., Legendre, P., McGlinn, D., Minchin, P. R., O’Hara, R. B., Simpson, G. L., Solymos, P., Stevens, M. H. H., Szoecs, E., and Wagner, H., 2019. Package 'vegan': Community Ecology Package Version 2.5-6. http://cran.ism.ac.jp/web/packages/vegan/ vegan.pdf

Parke, J. L., Knaus, B. J., Fieland, V. J., Lewis, C., and Grünwald, N. J. 2014. Phytophthora community structure analyses in Oregon nurseries inform systems approaches to disease management. Phytopathology 104:1052-1062.

Parsons, M. W., and Munkvold, G. P. 2010. Associations of planting date, drought stress, and insects with Fusarium ear rot and fumonisin B1 contamination in California maize. Food Addit. Contam. 27:591-607.

Ragazzi, A., Moricca, S., Dellavalle, I., and Mancini, F. 1995. Infection of cotton by Fusarium oxysporum f. sp. vasinfectum as affected by water stress. Phytoparasitica 23:315-321.

Redekar, N. R., Eberhart, J. L., and Parke, J. L. 2019. Diversity of Phytophthora, Pythium, and Phytopythium species in recycled irrigation water in a container nursery. Phytobiomes J. 3:31-45.

Ristaino, J. B. 1991. Influence of rainfall, drip irrigation, and inoculum density on the development of phytophthora root and crown rot epidemics and yield in bell pepper. Phytopathology 81:922-929.

Ristvey, A. G., Belayneh, B. E., and Lea-Cox, J. D. 2019. A comparison of irrigation-water containment methods and management strategies between two ornamental production systems to minimize water security threats. Water $11: 2558$

Rojas, J. A., Jacobs, J. L., Napieralski, S., Karaj, B., Bradley, C. A., Chase, T., Esker, P. D., Giesler, L. J., Jardine, D. J., Malvick, D. K., Markell, S. G., Nelson, B. D., Robertson, A. E., Rupe, J. C., Smith, D. L., Sweets, L. E., Tenuta, A. U., Wise, K. A., and Chilvers, M. I. 2017. Oomycete species associated with soybean seedlings in North Americapart I: Identification and pathogenicity characterization. Phytopathology 107: 280-292.

Rooney-Latham, S., Blomquist, C. L., Kosta, K. L., Gou, Y. Y., and Woods, P. W. 2019. Phytophthora species are common on nursery stock grown for restoration and revegetation purposes in California. Plant Dis. 103: 448-455

Schwingle, B. W., Smith, J. A., and Blanchette, R. A. 2007. Phytophthora species associated with diseased woody ornamentals in Minnesota nurseries. Plant Dis. 91:97-102.

Shahzad, R., Khan, A. L., Bilal, S., Asaf, S., and Lee, I. J. 2018. What is there in seeds? Vertically transmitted endophytic resources for sustainable improvement in plant growth. Front. Plant Sci. 9:24.

Sikora, R. A., Pocasangre, L., zum Felde, A., Niere, B., Vu, T. T., and Dababat, A. A. 2008. Mutualistic endophytic fungi and in-planta suppressiveness to plant parasitic nematodes. Biol. Control 46:15-23.

Starke, R., Bastida, F., Abadía, J., García, C., Nicolás, E., and Jehmlich, N. 2017. Ecological and functional adaptations to water management in a semiarid agroecosystem: A soil metaproteomics approach. Sci. Rep. 7:10221.

Summerell, B. A. 2019. Resolving Fusarium: Current status of the genus. Annu. Rev. Phytopathol. 57:323-339.

Swett, C. L. 2020. Managing crop diseases under water scarcity. Annu. Rev. Phytopathol. 58:387-406.

Torres, D. E., Rojas-Martínez, R. I., Zavaleta-Mejía, E., Guevara-Fefer, P., Márquez-Guzmán, G. J., and Pérez-Martínez, C. 2017. Cladosporium cladosporioides and Cladosporium pseudocladosporioides as potential new fungal antagonists of Puccinia horiana Henn., the causal agent of chrysanthemum white rust. PLoS One 12:e0170782.

USDA-NASS. 2019. Floriculture crops 2018 summary. United States Department of Agriculture-National Agricultural Statistics Service. https://www. nass.usda.gov/Publications/Todays_Reports/reports/floran19.pdf

Waqas, M., Khana, A. L., Hamayuna, M., Shahzad, R., Kang, S.-M., Kim, J.-G., and Lee, I.-J. 2015. Endophytic fungi promote plant growth and mitigate the adverse effects of stem rot: An example of Penicillium citrinum and Aspergillus terreus. J. Plant Interact. 10:280-287.

Warner, L. A., Lamm, A. J., Beattie, P., White, S. A., and Fisher, P. R. 2018. Identifying opportunities to promote water conservation practices among nursery and greenhouse growers. HortScience 53:958-962.

Warnes, G. R., Bolker, B., Bonebakker, L., Gentleman, R., Liaw, W. H. A., Lumley, T., Maechler, M., Magnusson, A., Moeller, S., Schwartz, M. and Venables, B. 2020. gplots: Various R Programming Tools for Plotting Data. ScienceOpen. https://www.scienceopen.com/document?vid= 0e5d8e31-1fe4-492f-a3d8-8cd71b2b8ad9

Weiland, J. E. 2011. Influence of isolation method on recovery of Pythium species from forest nursery soils in Oregon and Washington. Plant Dis. 95:547-553.

Weiland, J. E., Scagel, C. F., Grünwald, N. J., Davis, E. A., Beck, B. R., and Fieland, V. J. 2018. Variation in disease severity caused by Phytophthora cinnamomi, P. plurivora, and Pythium cryptoirregulare on two rhododendron cultivars. Plant Dis. 102:2560-2570

White, S. A., Owen, J. S., Majsztrik, J. C., Oki, L. R., Fisher, P. R., Hall, C. R., Lea-Cox, J. D., and Fernandez, R. T. 2019. Greenhouse and nursery water management characterization and research priorities in the USA. Water $11: 2338$.

White, T. J., Bruns, S., Lee, S., Taylor, J. 1990. Amplification and direct sequencing of fungal ribosomal RNA genes for phylogenetics. Pages 315-322 in: PCR Protocols: A Guide to Methods and Applications. M. A. Innis, D. H. Gelfand, J. J. Sninsky, and T. H. White, eds. Academic Press, San Diego, CA, U.S.A.

Xu, J., Xu, X. D., Cao, Y. Y., and Zhang, W. M. 2014. First report of greenhouse tomato wilt caused by Plectosphaerella cucumerina in China. Plant Dis. 98:158.

Xue, A. G. 2003. Biological control of pathogens causing root rot complex in field pea using Clonostachys rosea strain ACM941. Phytopathology 93: 329-335.

Yang, L., Lu, X. H., Li, S. D., and Wu, B. M. 2018. First report of common bean (Phaseolus vulgaris) root rot caused by Plectosphaerella cucumerina in China. Plant Dis. 102:1849.

Yao, S., Merwin, I. A., Abawi, G. S., and Thies, J. E. 2006. Soil fumigation and compost amendment alter soil microbial community composition but do not improve tree growth or yield in an apple replant site. Soil Biol. Biochem. 38:587-599.

Zheng, Y., Hu, H. W., Guo, L. D., Anderson, I. C., and Powell, J. R. 2017. Dryland forest management alters fungal community composition and decouples assembly of root- and soil-associated fungal communities. Soil Biol. Biochem. 109:14-22. 